\title{
The Influence Of Single Parent Parenting Style On Social Emotional Development Women Student Of Al-Istiqamah Ngatabaru Modern Islamic Boarding School
}

\author{
Beti Wulandari ${ }^{*}$,Sagaf S. Pettalongi ${ }^{2}$, and Hamlan Hamlan ${ }^{3}$ \\ 1 Islamic Education Department, Postgraduate, Institut Agama Islam Negeri Palu \\ 2 Islamic Education Department, Postgraduate, Institut Agama Islam Negeri Palu \\ ${ }^{3}$ Islamic Education Department, Postgraduate, Institut Agama Islam Negeri Palu
}

\section{ABSTRACT}

This study was conducted in al-istiqamah ngatabaru modern islamic boarding school with sample of 50 students. Data were gathered through observation and questionnaires. The data were analysed using descriptive analysis approach. The results showed that the parenting style applied by each parents of students in general can be said to be quite democratic, but none of the parents of students who apply pure democratic parenting. Under certain circumstances, parents are authoritarian and in another circumstances parents are permissive. Based on the significant value of the Coefficients table, the significance value of $0,000<0,05$, then based on the known value of $t_{\text {count }}$, while the Ttable value at the error level $5 \%=2.011$, thus the statement can be written that, $\mathrm{t}_{\text {count }}>t_{\text {table }}(18.254<2.011)$, the degree of the influence of single parent parenting style on social emotional behavior women student of al-istiqamah ngatabaru modern islamic boarding school also can be known through the magnitude of coefficient of determination (R Square) is 0.871 or $87.1 \%$. This means that $12.9 \%$ is influenced by other factors not included in this study. so it can be concluded that single parent parenting style $(X)$ parenting variable influential to emotional social development variable $(\mathrm{Y})$, the result is significant hypothesis that there is positive influence between parenting parent single parent to emotional social development santriwati pondok pesantren modern Al-istiqamah Ngatabaru.
ARTICLE

INFORMATION

Keywords:

Single parent parenting style, social emotional development 


\section{Introduction}

Family education is at the heart and foundation of overall educational efforts. ${ }^{1}$ A family becomes one of the institutions that carry out the duties and responsibilities in achieving educational goals. The family provides the basis for the formation of behavior, character, morals, and education. The interaction experience in the family will also determine the pattern of child behavior towards others in the community, so parents are required to be obliged to take care of their children by using the appropriate means of parenting. Parenting is an important part of socialization, the process by which children learn to behave according to social expectations and standards.

The family became the first milestone in instilling the basics of education. Family education includes non-formal education, but we cannot simply set aside because, in the family, one can learn and develop not only academic skills but also good attitudes and behaviors. Parents have a mandate and responsibility in educating the child. Parenting and support patterns are indispensable to the child.

The pattern of foster care is generally directed at the way parents treat the child in various ways, whether in communicating, disciplining, monitoring, and encouraging proper parenting patterns according to their child's development. The child perceives the pattern of foster care given to him well. The pattern of foster care is the

\begin{tabular}{l}
\hline $1 \quad$ Mohamad Surya, Bina \\
Keluarga,(Semarang: Aneka Ilmu, Anggota IKPI, \\
2003) h. 2
\end{tabular}

attitude of parents in dissing their children. The treatment of a child's parents will affect how the child views, assesses, and also affects the parent and affects the quality of the relationship that develops between them. Parents who are with each other provide different parenting patterns in guiding and educating their children.

The simple form of the family consists of father, mother, and son. The first two components, father and mother, can be the components that determine the child's life, but the field's phenomenon shows that not all children have complete parents.

A child's life without parents is complete for various reasons, such as the head of the family who passed away earlier, died in the job, or the current trend is divorce. Many children feel sad, traumatized, angry, frustrated, afraid of facing this situation. ${ }^{2}$ Likewise, it is feared that children who are cared for by a single parent will have a negative impact on their child's development or education because parents who are single parents are usually unable to divide their time between work to meet family needs and duties as caregivers or educators in the family.

Emotional, social attitudes in children need attention from parents. The parents' emotional atmosphere can stimulate the development of the developing child's brain and developmental abilities. The child's psychological ignorance will lead to

2 Rusli, R. (2013). The Role of Musalahah in Conflict Resolution: A Historical Perspective. Hunafa: Jurnal Studia Islamika, 10(2), 203-220.

e-ISSN: 2715-4572 p-ISSN: 2716-1439 
various kinds of violence from the parents as the closest people in the form of physical, psychological, and even sexual violence. For example, physical violence, such as pinching, hitting, and ranges from mild violence to extreme doses. Psychic violence is like giving a stigma (bad stamp) "you are a naughty child, don't know yourself, dirty, stupid, and the like."

Based on the author's preliminary observations at the Al-istiqamah Ngatabaru Modern Islamic Boarding School, this boarding school is one of the schools that implements a boarding system in which all students are required to be at the campus for 24 hours. So for 24 hours, all students receive supervision and teaching guidance on campus. The modern Islamic boarding school Al-istiqamah Ngatabaru implements a boarding system so that everything that is seen, what is heard, and what the students do has educational value. In addition, the aim is that education and teaching can be carried out optimally and adequately because students are directly guided 24 hours by teachers who also live in the hostel for 24 hours.

However, there are also some students who are not maximal in following education and teaching at the Ngatabaru Modern Al-istiqamah Islamic Boarding School. Among them are students who are cared for by singleparent families. This happens because of the lack of support from the child's parents. Parents are too busy making a living to pay for family needs.

Some parents who send their children to the pesantren think that when a child leaves the pesantren to become a pious person, but in reality this is not the case, the parents' attention and parenting are the main factors for the success or failure of a child in taking education and teaching. Pesantren are only supporting facilities that parents can use so that children can receive good education and teaching. So, even though children stay for 24 hours in the pesantren are cared for and educated by the board of teachers at the pesantren, the phenomenon that occurs in modern Islamic boarding schools Al-istiqamah Ngatabaru is the impact of parenting at home before entering the pesantren. And receive education at the pesantren.

\section{Literature review}

\subsection{Parenting style for single-parent}

In educating children, there are various forms of parenting that parents can choose and use. Before proceeding to the next discussion, first we will discuss the meaning of parenting itself. Parenting consists of two words, namely pattern and upbringing. According to the Big Indonesian Dictionary, pattern means a fixed pattern, model, system, work method, form (structure). ${ }^{3}$ While the word foster can mean looking after (caring for and educating) small children, guiding (helping, training and so on), and leading (heading and administering) an agency or institution. ${ }^{4}$ More specifically, the word foster

3 Depdikbud, Kamus Besar Bahasa Indonesia, (Jakarta : Balai Pustaka, 1988), h. 54

4 TIM Penyusun Kamus Pusat Pembinaan dan Pengembangan Bahasa, Kamus Besar Bahasa Indonesia,(Jakarta : Balai Pustaka, 1988), Cet. Ke-1, h. 692 
includes all aspects related to maintenance, care, support, and assistance so that people can stand and live their lives in a healthy manner. ${ }^{5}$

Parenting style is the attitude and behavior of parents in interacting with children. ${ }^{6}$ These parents' attitudes and behavior can be seen from the way parents instill discipline in their children, influence emotions, and how parents control their children. With regard to the understanding of parenting styles, Hurlock explained parenting styles as a way for parents to educate their children. These namely, parents' efforts are realized in the form of structuring the physical environment, children's social environment, children's education, dialogue with their children, control of children's behavior, and determination of moral values towards their children. ${ }^{7}$

According to Ahmad Tafsir, parenting means education, while education is conscious guidance by educators of students' physical and spiritual development towards the formation of the main personality. ${ }^{8}$

According to Casmini, parenting is defined as how parents treat children, educate, guide, and discipline and protect children in reaching the

5 Elaine Donelson, Asih, Asah, Asuh Keutamaan Wanita, (Yogyakarta : Kanisius, 1990), Cet. Ke-1, h.5

${ }^{6}$ Rusli, R. (2014c). Teaching Usul al-Fiqh: A Multicultural Education Model. Al-Tahrir: Jurnal Pemikiran Islam, 14(2), 447-464.

7 Hurlock. Perkembangan Anak 3, (Jakarta: Erlangga, 1988), h. 256

8 Danny I. Yatim irwanto. Kepribadian Keluarga Narkotika ( Jakarta: Arcan, !991), Cet. Ke-, h. 94 maturation process, to efforts to form norms expected by society in general. ${ }^{9}$

Parenting is the best way parents can educate their children as a manifestation of a sense of responsibility to their children. Another definition of parenting between children and parents is the form of interaction between children and parents during parenting activities, which means parents educate, guide, discipline, and protect children from reaching maturity in accordance with the prevailing norms in the local environment and society. ${ }^{10}$

Monks provide an understanding of parenting as a way of parents, namely father, and mother, in providing love and parenting, which has a major influence on how children see themselves and their environment. ${ }^{11}$ Parents' role in caring for children is not only important to protect the child's mental development from negative things, but also to shape their character and personality so that they become spiritual beings who are always obedient to carrying out religious orders.

On the other hand, Baumrind in Casmini argues that in principle, parenting is parental control or supervision by parents to their children. Meanwhile, Sugihartono, and others explained that the parenting style is a

\footnotetext{
9 Casmini. Emotional Parenting: DasarDasar Pengasuhan Kecerdasan Emosi Anak, ( Yogyakarta: Pilar Media,2007), h. 47

10 Haris Clemes, Mengajarkan Disiplin Kepada Anak, ( Jakarta: Gramedia Widiasarana Indonesia, 2002), h. 89

11 Mohammad Takdir Ilahi, Quantum Parenting, (Jogjakarta: KATAHATI, 2013), Cet.
} Ke-1, h. 134

e-ISSN: 2715-4572 p-ISSN: 2716-1439 
pattern of behavior that is used to relate to their children. ${ }^{12}$

Parenting patterns are a description of the attitudes and behavior of parents and children in interacting and communicating during parenting activities. In this activity of providing care, parents will give attention, rules, discipline, rewards, and punishments, as well as respond to the wishes of their children. ${ }^{13}$ Parents' attitudes, behaviors, and habits are always seen, assessed, and imitated by their children, which then consciously or unconsciously will be absorbed, then become a habit for their children. ${ }^{14}$

So parenting is an overall interaction between parents and children, where parents intend to stimulate their children by changing the behavior, knowledge, and values that are considered the most appropriate by parents so that children can be independent, grow and develop healthily. And optimal.

\subsection{Characteristics of Children Due to Parenting Patterns}

Different parenting styles will also have a different impact in shaping the characteristics of each student. Below

12 Sugihartono, dkk. Psikologi Pendidikan. (Yogyakarta: UNY Press: 2007), h. 51

13 Sukaenah, S., Rusli, R., \& B, M. T. (2020).

The Effectiveness of Indonesia Supreme Court Regulation Number 1 Year 2016 Concerning Mediation of Marriage Disputes INTERNATIONAL JOURNAL OF CONTEMPORARY ISLAMIC LAW AND SOCIETY, 2(1), 63-80.

14 usli, R. (2020). The Role of Family in Preventing Social Conflict in Society From Islamic Perspectives. Hunafa: Jurnal Studia Islamika, 17(1), 108-122. will explain the characteristics that exist in children according to the effects on the three kinds of parenting styles above, which were stated by Sugihartono and others. ${ }^{15}$

a. Authoritarian parenting

This authoritarian parenting style, in which the parents' attitude in caring for their children, emphasizes power, discipline, and obedience to the parents. So it can be said that the attitude of parents like this, the child must always follow it and implement it because most parents like this will give quite harsh punishments or reprimands to their own children if the child does not follow the rules or orders of the parents. And children raised with this upbringing can become loners, experience setbacks in maturity, hesitate in acting, get nervous easily, and are slow to take the initiative. b. Permissive parenting

Permissive parenting style in which the parents' attitude in caring for their children can be said to be less authoritative, less assertive, too liberating, and sometimes indifferent or indifferent to the child. Parenting style like this is very bad and not recommended because the child will be arbitrary, and as he pleases. And the nature of this family is usually aggressive, unable to cooperate with others, less adaptable, unstable, and has an attitude of suspicion of others.

c. Democratic parenting

This authoritative parenting style, which is highly recommended in educating children because by using this parenting style, children are taught how

15 Sugihartono, dkk. Psikologi Pendidikan. (Yogyakarta: UNY Press. 2007), h. 31

e-ISSN: 2715-4572 p-ISSN: 2716-1439 
to be responsible, and are more able to adapt to new environments can be flexible, can control themselves, want to respect and accept suggestions, criticism, and opinions from others, be active and stable.

From the three types of parenting styles described above, it can be identified the influence of various kinds of parenting styles on children's social, and emotional development. Parents who apply authoritative parenting will fully involve their children in the division of responsibilities at home. It has a high level of control and requires children to act on an intellectual and social level according to their age and abilities. Because parents can be realistic about the abilities possessed by children and do not expect things that are too much and impose on children because parents are up to where the child's abilities are, parents also give freedom to children to develop children's creativity, as well as the freedom to choose and take action, but children must also be responsible for what they choose. Parents also approach children by being warm so that they feel comfortable and feel appreciated by the parents.

Meanwhile, parents who apply authoritarian parenting in which parents demand and control their children only so that the children obey their parents and also limit the children. Children with parents like this tend to have moderate competence and responsibility, tend to withdraw socially, and do not have an attitude of spontaneity. Girls are dependent on their parents and have no motivation to move forward. Boys tend to be more aggressive than other boys. Another with permissive parenting in which the child becomes uncontrollable because the child is not taught to be responsible, only given the freedom to act. In fact, children in their teens still really need direction and guidance from their parents.

\subsection{Ideal Parenting for Child Development}

Based on the impact of each parenting style's application, the ideal parenting style for child development is authoritative parenting. This is in line with the opinion of experts, including Baumrind.

Baumrind stated that the ideal parenting style for child development is authoritative parenting ${ }^{16}$. This is because:

a. Authoritative parents provide a balance between restriction and freedom. On the other hand, it provides opportunities for selfconfidence while setting standards, limits, and guidelines for children. Authoritative families are more adaptable to new stages of the family cycle.

b. Authoritative parents are flexible in caring for their children. They form and adjust demands and expectations according to the changing needs and competencies of their children. Authoritative parents prefer to give children gradual freedom.

c. Authoritative parents prefer to encourage children in conversation,

16 Casmini. Emotional Parenting: DasarDasar Pengasuhan Kecerdasan Emosi Anak, h. 51 
this can support intellectual development which is an important basis for the development of social competence.

d. Discussions in the family about decision making, rules. and the expectations explained can help children understand social systems and social relationships.

e. Authoritative families can stimulate thinking in children.

f. Authoritative parenting combines balanced control with warmth. So that children identify their parents. In general, those who treat us are full of warmth and affection.

g. Children who grow up with their parents' warmth will direct themselves by imitating their parents and then show similar tendencies.

h. Children who grow up in authoritative families will continue to practice authoritative parenting as well. Children are responsible, able to direct themselves, have curiosity, and have a calm self, reflecting the family's warmth, giving flexible instructions.

i. Parents feel comfortable around children who are responsible and free, so they treat adolescents warmer, on the other hand, teenagers who act up will make their parents think long, impatient, and distant.

In line with Baumrind's opinion, Hart and others in Santrock also suggest that authoritative parenting is suitable/ideal to be applied. ${ }^{17}$ This is because:

\footnotetext{
${ }^{17}$ John W Santrock, Perkembangan Anak.
} (Jakarta: Salemba Humanika 2007)., h. 168 a. Authoritative parenting is the right balance between control and autonomy. So as to provide opportunities for children to establish independence and provide standards, limits, and guidelines that children need.

b. Authoritative parents are more likely to involve their children in a verbal tp give and take and allow them to express their views.

The warmth and involvement of parents provided by authoritative parents make children more receptive to parental influence. Based on the explanation of the experts' opinions above, it can be concluded that authoritative parenting is a parenting style that has a greater positive impact than its negative impact. Authoritative parenting can be said to be an ideal parenting style for child development.

\subsection{As a result of the emergence of a single parent family}

Single-parent families will get double duty. If there is the absence of a father, the mother's role is increased as a seeker for sustenance and a child caregiver. Even though the family has many roles (functions) that must be carried out. ${ }^{18}$ These functions are as follows:

a. Biological Functions

The biological function is related to meeting the sexual needs of husband and wife. Parents are the principal institutions that legally provide money for the regulation and organization of sexual gratification. However, there are

${ }^{18}$ Hendi Suhendi, Dkk. Pengantar Studi Sosiologi Keluarga, h. 45

e-ISSN: 2715-4572 p-ISSN: 2716-1439 
also societies that tolerate different institutions that take over the function of sexual regulation, for example, entertainment venues and massage parlors. This fact is basically an obstacle, and at the same time, a very complicated thing to think about. the continuity of a family is largely determined by the success of having a biological relationship. If one of the partners then fails to carry out his biological function, it is possible that there will be disturbances in the family that usually struggle with divorce in polygamy.

a. Children's socialization function

The socialization function refers to the role of the family in shaping the child's personality. Through this function, the family tries to prepare provisions for the attitudes, beliefs, ideals, and values adopted by the community and learn the roles they are expected to play. Thus, socialization means carrying out a learning process for a child. Learning is not always defined as an activity that is purely intellectual in nature but also includes other things, namely observation. Through the teaching and learning process in this family, children know how to think from the group.

b. Child socialization function

In line with that, good or bad socialization in the family will affect its members. Abdullah Nasikh Ulwan in Hendi said that children are a mandate that relies on the shoulders of their parents. Its pure heart, like priceless pearls. If he is accustomed and educated by kindness, they will grow up to be a good happy person in this world and the hereafter. If left to ugliness like an animal, they will undoubtedly be damaged and suffer. If that is the case, it is difficult to educate and direct.

The socialization process should not be given to other people. Parents' role is very big in this socialization process because children will imitate everything they see and learn from their parents. If parents do not carry out the socialization function properly, the problem that arises is that the child loses attention. After that, they looked for other characters besides their parents to emulate.

All communities depend very much on families in terms of socialization as a preparation for entering adulthood so that children can play a positive role in society. One way is through modeling for children. Children learn to be men, husbands, and fathers with a family that is actually led by a man. Socialization will find it difficult if such a model does not exist, and when the child has to rely on the model witnessed in other families. In the socialization process, there are no substitute roles for father and mother that are truly satisfying. A number of recent studies have concluded that the main reason for differences in children's intellectual achievement is the family atmosphere. This kind of study further confirms that the family is the main determining factor for children's socialization.

On the other hand, in a very difficult family, and facing various problems of suffocating poverty, socialization problems in the family cannot run normally. Families like this 
will socialize children and dependence on their parents.

Socialization for humans continues as long as he is alive, from the time he is born until he dies. The process and form of socialization by each human being are very different and depend on the person's time being. At least, the human life cycle is determined by several periods, namely childhood, adolescence, adulthood, old age, and the time to death.

1) Socialization in childhood

Parents have an obligation to teach their children about everything. This obligation is a form of the role of parents in socialization. In childhood, parents are the sole agents for children in socializing.

2) Socialization in the teenagers

At this time, a person is in a transitional period, which is leaving childhood and entering adolescence. This period is also known as reserve socialization, where younger people can influence older people. In other words, reserve socialization means people who should be socialized but instead socialize. This process occurs in societies that are experiencing rapid change.

Socialization agents in adolescence are no longer parents but peers, playgroups, and possibly the opposite sex. At this time, there is very little dependence on parents because he gets new values more widely outside of his parents.

\section{3) Socialization in adulthood}

The socialization process is experienced by adults when they get a new role. For adults, these new roles could include getting a job, getting married, and having children. The three forms of the role require someone to do learning. All of these new roles require the adult to start over from scratch as he learns to socialize again.

4) Socialization towards the old age people

An elderly person is like a teenager who experiences a transition from a productive period to a time towards death. At this time, he also depended a lot on others. Here they look like a child who is physically dependent on the child or siblings. ${ }^{19}$ In fact, sometimes elderly parents are seen as non-person, which means they are there, but their existence has little meaning.

The socialization process for them is carried out in stages. At the age of 60 years, a person has realized to reduce his workload. They then accept that leisure is a substitute activity for them to work.

c. Fungsi Afeksi

One of the basic human needs is the need for love or love. The psychiatric view says that the main cause of emotional, behavioral, and even physical health disorders. Because it's lacking love, that is, the absence of warmth and affectionate relationships in an intimate environment. Many facts show that the need for friendship and intimacy is very important for children. The data show that serious children's wear is one of the characteristics of children who do not get attention or feel affection.

This need for affection is a very important need for someone. Many unmarried people are truly happy,

19 Rusli, R. (2013). The Role of Musalahah in Conflict Resolution: A Historical Perspective. Hunafa: Jurnal Studia Islamika, 10(2), 203-220.

e-ISSN: 2715-4572

p-ISSN: 2716-1439 
healthy, and useful. Therefore, the need for affection is expected to be played by the family.

Recently, many social groups have emerged that are able to meet the needs of friendship and affection. Of course, this group is an indirect extension of the affective function in the family. However, it needs to be watched out if other groups outside the family then take over the need for affection.

This recent trend shows that the affection function has shifted to other people, especially for those whose parents work outside the home. As a consequence, the child is no longer close psychologically because the child considers his parents to have no attention. Even worse, the wife who works outside the home always spoils her children with luxury items (materialistic objects), even though the real need for the child is not that, neglecting the intimacy, care, and sincere affection of the mother. Furthermore, a mother who works outside the home will spoil her child. This was done because of the "guilt" towards their children due to not seeing each other all day. Therefore, another impact that arises is the lax value of parental control over children and tolerance for children's actions that violate ethics. This is compensation that seems difficult to avoid for mothers who work outside the home.

\section{d. Educational Functions}

The family is the first teacher in educating humans. This can be seen from the growth of a child from a baby, learning to take walks, to being able to walk. Everything is taught by the family.
One example of family function as an educational tool can be seen in Javanese and Sundanese families. A child who receives a gift from another must receive with his right hand. If not with the right hand, the gift will be withdrawn. On the other hand, if you use your right hand, the gift will really be given. ${ }^{20}$

The family's responsibility to educate their children has been largely or even entirely taken by formal and non-formal educational institutions. Therefore, the latent function of education for children appears, namely the weakening of parental supervision. Parental authority over children is reduced by the school. In fact, it is not uncommon for a child to find new values that are very contrary to the values of his parents, which he may ridicule.

In Indonesian society today, the function of the family is increasingly developing, including the function of religion, which encourages the development of the family and all its members to become religious people who are full of faith and devotion to God Almighty.

\section{Methodology}

This study uses a quantitative approach to survey techniques. The research object was the modern Al-

20 Evita, E., Syahid, A., \& Nurdin, N. (2019). Understanding Students' Learning Outcomes Differences Through the Application of the Market Place Activity Type of Cooperative Learning Model and the Application of Conventional Learning Models International Journal of Contemporary Islamic Education, 1(1), 6785. 
istiqamah Ngatabaru Islamic boarding school students, totaling 50 students who were randomly selected.

The calculation of the data analysis in quantitative research is descriptive and statistical analysis and has inferential statistics using SPS 16 and Microsoft Excel 2007 program. ${ }^{21}$ Descriptive statistics aim to obtain an overview of respondents, while inferential statistics are used for hypothesis testing. Hypothesis and analysis are tested using software, namely SPSS $16 .^{22}{ }^{23}$ The data obtained were tested with a simple linear regression analysis model to test the independent and dependent variables' effect.

\section{Result and Discussion}

\subsection{Reliability Test}

A reliability test is a statistical test used to determine the reliability of a series of question items in measuring variable reliability. The reliability test is

${ }^{21}$ Nurdin, N., Pettalongi, S. S., \& Ahsan, M. N. (2019). Implementation of Teaching Quality Assessment System Using Android. 2019 5 th International Conference on Science and Technology (ICST)

22 Nurdin, N., Pettalongi, S. S., \& Mangasing, M. (2019). Understanding Digital Skill Use from The Technology Continuance Theory (TCT). 2019 6th International Conference on Information Technology, Computer and Electrical Engineering (ICITACEE),

${ }^{23}$ Marzuki, M., \& Nurdin, N. (2020). The Influence of Halal Product Expectation, Social Environment, and Fiqih Knowledge on Intention to Use Shariah Financial Technology Products. International Journal of Innovation, Creativity and Change, 13(1), 171-193. intended to find out whether the data collection tool basically shows the level of accuracy, stability, or consistency when re-testing the same symptoms. The reliability test in this study used the assistance of the IBM SPSS 16 for windows program provided that if negligent $>0.50$, then the reliability is perfect. If negligence is between $<0.50$, then the reliability is low. The reliability test was carried out on two variables, namely the single parent parenting style variable $(X)$ and the social-emotional development variable $(\mathrm{Y})$.

Based on the results of processing using the IBM SPSS for windows 16 program, the reliability test results of the $X$ variable are obtained as summarized in the table below:

Table 1. Reliability test for Variabel (X)

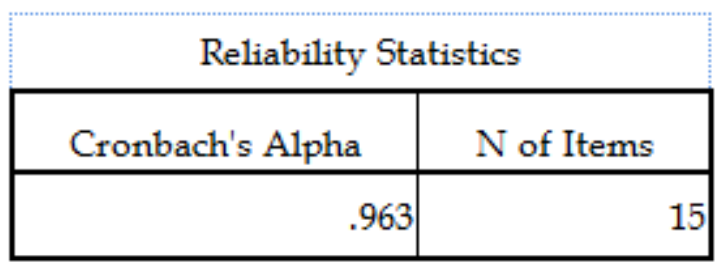

Based on the results of the table above, it is known that the instrument shows an Alpha coefficient of 0.96, meaning that the questionnaire can be said to be reliable because it is $0.96 \geq$ 0.50. This means that the research instrument, in its function of size, has high reliability to produce consistency of measurements in the influence of parenting. Single parent to the socialemotional development of students for the purposes of testing the research hypothesis.

While the reliability test of the $Y$ variable. Based on the results of processing using the IBM SPSS for 
windows 16 program, the results are as summarized in the table below: Table 2. Reliability Test for Variabel (Y)

\begin{tabular}{|r|r|}
\hline \multicolumn{2}{|c|}{ Reliability Statistics } \\
\hline Cronbach's Alpha & N of Items \\
\hline .970 & 18 \\
\hline
\end{tabular}

Based on the results of the table above, it is known that the instrument shows an Alpha coefficient of 0.97, which means that the questionnaire can be said to be reliable because it is $0.97 \geq$ 0.50. That means that the research instrument, in its function of size, has high reliability to produce consistent measurements in the influence of parenting. Single parent to the socialemotional development of students for the purposes of testing the research hypothesis.

\subsection{Validity test}

The validity test is carried out to measure the questions or statements in the questionnaire, whether the questions or statements in the questionnaire measure the concept in question. A question is able to express what is expressed or what you want to measure. Thus, validity is closely related to the accuracy of the measurement results of a measuring instrument. It can be said to be valid if the statement on the questionnaire can reveal something that is measured by the questionnaire. It is said to be valid if the Kaiser-MeyerOlkin Measure values, Anti Image Correlation and Rotated Component Matrix are $>0.50$.
For this reason, the calculation of the validity test is carried out with the help of the IBM SPSS for windows 16 program computer. Based on the test results of the validity test of each statement indicator every variable, the results are obtained in the table as follows:

To perform a factor analysis, there are two assumptions that must be fulfilled, namely the KMO MSA index must be> 0.50 and Bartlett's Test of Sphericity index must be at a significant level $<0.50$. If these two assumptions are fulfilled, then the factor analysis can be continued. The KMO and Bartlett's Test of Sphericity tables are as follows:

Table.3 KMO and Bartlett's Test of Sphericity Variabel $(X)$

KMO and Bartlett's Test

\begin{tabular}{|ll|r|}
\hline Kaiser-Meyer-Olkin Measure of & .939 \\
Sampling Adequacy. & \\
Bartlett's Test of & Approx. & 636.892 \\
Sphericity & Chi-Square & 105 \\
& df & .000 \\
\hline
\end{tabular}

From the table, it can be seen that the data meet these two assumptions $\mathrm{KMO} \mathrm{MSA}=0.93$ (far above the critical value of 0.50 ) and Bartlett's Test of Sphericity $=0.000$ (far below the critical value of 0.50 . 
Table 4. KMO and Bartlett's Test of Sphericity Variabel $(Y)$

KMO and Bartlett's Test

\begin{tabular}{|c|c|c|}
\hline \multicolumn{2}{|c|}{$\begin{array}{l}\text { Kaiser-Meyer-Olkin } \\
\text { Measure of Sampling } \\
\text { Adequacy. }\end{array}$} & .924 \\
\hline \multirow{3}{*}{$\begin{array}{l}\text { Bartlett's } \\
\text { Test of } \\
\text { Sphericity }\end{array}$} & $\begin{array}{l}\text { Approx. } \\
\text { Chi-Square }\end{array}$ & 855.771 \\
\hline & df & 190 \\
\hline & Sig. & .000 \\
\hline
\end{tabular}

From the table above, it can be seen that the data fulfill these two assumptions $\mathrm{KMO}$ MSA $=0.92$ (far above the critical value of 0.50 ) and Bartlett's Test of Sphericity $=0.000$ (far below the critical value of 0.50 .

\subsection{Single Parenting Method}

The data on the frequency of parenting styles for single parents is obtained from a questionnaire that the author distributes to respondents. For more details, the authors will describe the following:

Table 5. Frequency of Single Parenting Method

\begin{tabular}{|c|c|c|}
\hline $\begin{array}{c}\text { Single Parenting } \\
\text { Method }\end{array}$ & Frequency & Percentage \\
\hline Otoriter & 10 & $20 \%$ \\
\hline Permisif & 15 & $30 \%$ \\
\hline Demokratis & 25 & $50 \%$ \\
\hline Jumlah & 50 & $100 \%$ \\
\hline
\end{tabular}

The results showed that most of the respondents experienced Democratic parenting, namely 25 respondents, and was followed by Permissive parenting, namely 15 respondents, then a small proportion of respondents experienced authoritarian parenting, namely 10 respondents. It can be seen from the results of respondents' answers to the questionnaire given by the researcher. Respondents stated that parents give children freedom in their opinions and carry out any activities that children like. However, in addition to giving freedom to children, parents also take part in controlling children's attitudes and behavior. So that in carrying out their activities, children feel free in appreciating their talents but still in the right corridor or path because there are parents who always supervise and direct.

The results of further research indicate that a small proportion of respondents are cared for using authoritarian parenting, namely as many as 10 respondents. The authoritarian parenting style applied by a small proportion of respondents can be seen from the respondents' answers to the researcher's questionnaire. Respondents stated that parents punish their children for not obeying their orders, and parents make strict rules. The respondents stated that parents were angry when they heard their children argue with their words. This shows that the way of the person receiving authoritarian parenting from their parents so far.

Authoritarian parenting tends to set standards that absolutely must be obeyed, usually accompanied by threats. For example, the child must obey the parents' rules and must not argue. Parents tend to look for the child's mistakes and then punish them or a difference of opinion between the parent 
and the child. The child is considered insubordinate and must obey all the wishes of the parents. This can create pressure and make children vulnerable to stress and depression.

Based on the research results, in addition to authoritarian and democratic parenting, it was also found that the respondents got Permissive parenting styles. The frequency of Permissive parenting applied by parents to their children can be seen from the results of the study. Where there are some respondents who stated that they were given freedom by their parents to behave, and parents allowed their children to behave badly. Besides, parents let their children choose what they wanted to do and do it. This shows that some respondents get parenting in the Permissive category from their parents.

The parenting style applied by these parents causes the child to behave at will without any control, and all the child's wishes based on the child's own will. The impact of this parenting pattern is that the child becomes uncontrollable, the child's behavior is uncontrollable because there is no control from the parents, it is not organized, the child also does not have goals to be achieved and the child is prone to deviant behavior.

In general, the parenting styles adopted by each student's parents are quite democratic. However, none of the students' parents apply genuine democratic parenting. In certain conditions, parents are authoritarian, and in certain conditions, parents are permissive.
Based on the analysis of the results of the hypothesis test, it was found that the results of the parenting style of single parents had a positive relationship with the social and emotional development of the students of the Al-Istiqamah Ngatabaru modern Islamic boarding school. Parents defer the primary and first educators for their children because it is from them that the first child receives education. Thus the first form of education is found in family life. Parents serve as caregivers, mentors, caregivers, and educators for their children. Every parent would want their children to be smart, intelligent, and have good morals. Parents are the most important factor in instilling the basis of personality, especially in enhancing their social, emotional development.

The effect of single-parent parenting on the social-emotional development of santriwati of the modern Islamic boarding school Alistiqamah Ngatabaru is said to be significant (accepted). Because, based on the significant value of the Coefficients table, a significance value of $0.00<0.05$ is obtained, then based on the $t$ value, the value is known, $t_{\text {count }}$ is 18,254 while the $t_{\text {table }}$ value is at an error level of $5 \%=2.011$. Thus the statement can be written that $t_{\text {count }}>t_{\text {table }}(18.254>$ 2.011).

The level of influence of single parent parenting patterns on the social emotional development of santriwati of modern Islamic boarding school Alistiqamah Ngatabaru can also be seen through the coefficient of determination (R Square) is 0.871 or $87.1 \%$. This means 
that $12.9 \%$ is influenced by other factors not included in this study. So it can be concluded that the variable single parent parenting style $(X)$ affects the social-emotional development variable (Y). The result is a significant hypothesis that states that there is a positive influence between singleparent parents' parenting style on the emotional, social development of Islamic boarding school santriwati Alistiqamah. Ngatabaru.

\section{Conclusion}

Based on the analysis and interpretation that has been carried out, the writer can conclude that the parenting styles applied by each of the parents of students are generally quite democratic, but none of the students' parents apply genuine democratic parenting. In certain conditions, parents are authoritarian, and in certain conditions, parents are permissive.

The influence of single-parent parenting patterns on their socialemotional development of santriwati modern Islamic boarding school Alistiqamah Ngatabaru is said to be significant (accepted), because based on the significant value of the Coefficients table, a significance value of $0.00<0.05$ is obtained, then based on the $t$ value, the value is known. $\mathrm{T}_{\text {count }}$ is 18,254 while the $t_{\text {table }}$ value is at an error level of $5 \%=$ 2.011. Thus the statement can be written that $t_{\text {count }}>t_{\text {table }}(18.254>2.011)$, the level of influence of single parent parenting patterns on the emotional social behavior of santriwati of modern Islamic boarding school Al-istiqamah Ngatabaru can also be seen through the coefficient of determination ( $\mathrm{R}$ Square) is 0.871 or $87.1 \%$.

This means that $12.9 \%$ is influenced by other factors not included in this study. So it can be concluded that the variable single parent parenting style $(X)$ affects the social-emotional development variable $(Y)$. The result is a significant hypothesis which states that there is a positive influence between the parenting style of single-parent parents on the emotional, social development of Islamic boarding school santriwati Al-istiqamah, Ngatabaru.

\section{REFERENCES}

Arikunto, S. (2006). Prosedur Penelitian Suatu Pendekatan Praktik. Jakarta: PT. Rineka Cipta.

Budiningsih, A. (2008). Belajar dan Pembelajaran. Jakarta : Rineka Cipta.

Dariyo. (2011) Psikologi Perkembangan Anak Tiga Tahun Pertama. Jakarta: PT Refika Aditama.

Departemen Pendidikan Nasional. (2008). Kamus Besar Bahasa Indonesia. Jakarta: PT. Gramedia Pustaka Utama.

Depdikbud. (1988) Kamus Besar Bahasa Indonesia. Jakarta: Balai Pustaka.

Desmita. (2005), Psikologi Perkembangan. Bandung: Remaja Rosdakarya.

Djamarah, Syaiful Bahr.(1994). Prestasi Belajar Dan Kompetensi Guru. Surabaya: Usaha Nasional.

Donelson, Elaine. (1990), Asih, Asah, Asuh Keutamaan Wanita, Yogyakarta : Kanisius. Cet. Ke-1.

Esa Nur Wahyuni. (2008). dan Baharuddin, Teori Belajar dan 
Pembelajaran, Jogjakarta: Ar-Ruzz Media Group, Cet. 3.

Evita, E., Syahid, A., \& Nurdin, N. (2019). Understanding Students' Learning Outcomes Differences Through the Application of the Market Place Activity Type of Cooperative Learning Model and the Application of Conventional Learning Models International Journal of Contemporary Islamic Education, 1(1), 67-85.

Fakhruddin, Asef Umar. (2011), Terapan Quantum Learning untuk Keluarga. Yogyakarta: Laksana.

Fuaduddin. (2009) Pengasuhan anak dalam keluarga Islam. Jakarta: Lembaga kajian Agama dan Jender.

Gunarsa, S.D. (2000). Azas psikologi Keluarga Idaman, Jakarta: BPK Gunung Mulia.

Hassan Sadily Dan John M. Echol. (2000), Kamus Inggris Indonesia. Jakarta: PT. Gramedia.

Hurlock. (1988). Perkembangan Anak 3. Jakarta: Erlangga.

Hawadi. (2004). Akselerasi: A-Z Program Percepatan Belajar dan Anak Berbakat Intelektual. Jakarta: PT. Gramedia Widiasarana Indonesia.

Marzuki, M., \& Nurdin, N. (2020). The Influence of Halal Product Expectation, Social Environment, and Fiqih Knowledge on Intention to Use Shariah Financial Technology Products. International Journal of Innovation, Creativity and Change, 13(1), 171193.
Nasution. (2009). Metode Research: Penelitian Ilmiah. Jakarta: Bumi Aksara.

Nurdin, N., Pettalongi, S. S., \& Ahsan, M. N. (2019). Implementation of Teaching Quality Assessment System Using Android. 2019 5th International Conference on Science and Technology (ICST)

Nurdin, N., Pettalongi, S. S., \& Mangasing, M. (2019). Understanding Digital Skill Use from The Technology Continuance Theory (TCT). 2019 6th International Conference on Information Technology, Computer and Electrical Engineering (ICITACEE)

Prayitno, Elida. (2006), Psikologi dewasa. Padang: Angkasa Raya.

Purwanto, M. Ngalim. (2008), Prinsipprinsip dan Teknik Evaluasi Pengajaran, Bandung: PT. Remaja Rosdakarya, , Cet.ke- 14.

Riduwan. (2010). Metode dan Teknik Menyusun Tesis. Bandung: Alfabeta.

Rusli, R. (2013). The Role of Musalahah in Conflict Resolution: A Historical Perspective. Hunafa: Jurnal Studia Islamika, 10(2), 203220.

Rusli, R. (2013). The Role of Musalahah in Conflict Resolution: A Historical Perspective. Hunafa: Jurnal Studia Islamika, 10(2), 203220.

Rusli, R. (2014c). Teaching Usul al-Fiqh: A Multicultural Education Model. Al-Tahrir: Jurnal Pemikiran Islam, 14(2), 447-464. 
Rusyan, A. Tabrani dkk.(1989), Pendekatan dalam Proses Belajar Mengajar, Bandung: CV. Remadja Karya, Cet. 1.

Santoso, Soegeng. (2012), Pendidikan Anak Usia Dini. Jakarta: Yayasan Citra Pendidikan Indonesia.

Slameto. (2003). Belajar dan faktor-faktor yang mempengaruhinya. Jakarta: PT Rineka Cipta.

Sudjana, N. (2005). Tuntunan Penyusunan Karya Ilmiah. Bandung: Sinar Baru Algesindo.

Sugiharto. (2007). Pengaruh Sifat Pola Asuh Orang Tua dan Cara Belajar Siswa Terhadap Prestasi Belajar Dalam Bidang Studi Akuntansi. Jurnal Pendidikan Ekonomi. Vol. 2, No. 3.

Sugiyono. (2012). Metode Penelitian Kuantitatif, kualitatif dan $R \mathcal{E} D$. Bandung: Alfabeta.

Sukaenah, S., Rusli, R., \& B, M. T. (2020). The Effectiveness of Indonesia Supreme Court Regulation Number 1 Year 2016 Concerning Mediation of Marriage Disputes INTERNATIONAL JOURNAL OF CONTEMPORARY ISLAMIC LAW AND SOCIETY, 2(1), 63-80.

Sukarmin, Sujono Riyadi. (2012), Asuhan Keperawatan Pada Anak. Yogyakarta: Graha Ilmu.

Sukmadinata, Nana Saudih. (2003). Landasan Psikologi Proses Pendidikan. Bandung: PT. Remaja Rosda Karya.

Supranto, Johannes. (2003). Metode Riset Aplikasinya Dalam Pemasaran. Jakarta: Rineka Cipta.
Surya, Mohamad.(2003) Bina Keluarga. Semarang: Aneka Ilmu, Anggota IKPI.

Suwartono. (2014). Dasar-dasar Metodologi Penelitian. Yogyakarta: CV ANDI OFFSET.

Syah, Muhibbin. (2000). Psikologi Pendidikan dengan Pendekatan Baru, (Bandung: PT.Remaja Rosda Karya. Cet. Ke- 5.

Takdir Ilahi, Mohammad. (2013), Quantum Parenting. Jogjakarta: KATAHATI. Cet. Ke-1.

Thoha, Chabib. (2006), Kapita Selekta Pendidikan Islam.Yogyakarta: Pustaka Pelajar.

Tirtonagoro, S. (2001). Anak Supernormal dan Program Pendidikannya. Jakarta: Bina Aksara.

Veithzal Rifa'i, Upaya-upaya Meningkatkan Hasil Belajar Kepemimpinan Peserta Diklat Spama Survei di DiklatDepkes, (Jurnal Pendidikan dan Kebudayaan No.40, tahun ke-9.Jakarta : Depdiknas, 2003).

Yatim D.I., dan Irwanto. (1991). Kepribadian Keluarga dan Narkotika. Jakarta: Arcan.

Yusuf, S. (2005). Psikologi Perkembangan Anak dan Remaja. Bandung: Remaja Rosdakarya.

Yusuf, Syamsyu. (2003), Psikologi Perkembangan Anak dan Remaja. Bandung: PT. Remaja Rosdakarya. 